\title{
PENGARUH PRODUK DAN PROMOSI TERHADAP KEPUTUSAN PEMBELIAN SMARTPHONE MEREK VIVO DI KOTA LUBUKLINGGAU (STUDI KASUS DI RATU 3G PONSEL)
}

\author{
Yuli Efrianti $^{1}$, Almusadad ${ }^{2}$ \\ 1,2Program Studi Manajemen, Universitas Bina Insan Lubuklinggau \\ E-mail : ${ }^{1}$ yuli_efriyanti@univbinainsan.ac.id, ${ }^{2}$ almusadat_mnj@gmail.com
}

\begin{abstract}
ABSTRACK
This study aims to determine the Effect of Products and Promotions on VIVO Brand Smartphone Purchasing Decisions in Lubuklinggau City. This research is a type of quantitative research. The research sample was 40 people. In this study using primary and secondary data sources. The results of the study of Product Variables partially influenced the VIVO Brand Smartphone Purchase Decision variable in Lubuklinggau City, this was evidenced from the tcount greater than ttable, which was 5.871>2.021 and a significant level of sig $=0.10$. Promotion variable partially influences the VIVO Brand Smartphone Purchase Decision variable in Lubuklinggau City, this is evidenced from the tcount greater than ttable, namely 3,441> 2,021 and a significant level of sig $=0.10$. Product and Promotion variables simultaneously influence the VIVO Brand Smartphone Purchase Decision in Lubuklinggau City, this is evidenced from the fcount value $=56,853$ greater than the ftabel value $=3.25$ and theprobability $($ sig. 0,000$)$ is smaller or less than 0.05 .
\end{abstract}

Keywords : Product, Promotion, Purchase Decision, Smartphone

\begin{abstract}
ABSTRAK
Penelitian ini bertujuan untuk mengetahui pengaruh produk dan promosi terhadap keputusan pembelian smartphone merek VIVO di Kota Lubuklinggau. Penelitian ini adalah jenis penelitian kuantitatif. Sampel penelitian berjumlah 40 orang. Dalam penelitian ini menggunakan sumber data primer dan sekunder. Hasil penelitian variabel produk berpengaruh secara parsial terhadap variabel Keputusan Pembelian Smartphone Merek VIVO di Kota Lubuklinggau, hal tersebut dibuktikan dari nilai $\mathrm{t}_{\text {hitung }}$ lebih besar dari $\mathrm{t}_{\text {tabel, }}$ yaitu 5.871> 2,021 dan tingkat signifikan sig $=0,10$. Variabel Promosi berpengaruh secara parsial terhadap variabel Keputusan Pembelian Smartphone Merek VIVO di Kota Lubuklinggau, hal tersebut dibuktikan dari nilai $t_{\text {hitung }}$ lebih besar dari $t_{\text {tabel, }}$ yaitu $3.441>2,021$ dan tingkat signifikan sig = 0,10. Variabel Produk dan Promosi berpengaruh secara simultan terhadap Keputusan Pembelian Smartphone Merek VIVO di Kota Lubuklinggau, hal tersebut dibuktikan dari nilai $\mathrm{f}_{\text {hitung }}$ sebesar $=56.853$ lebih besar dari nilai $\mathrm{f}_{\text {tabel }}=$ 3,25 dan probabilitas (sig. 0.000) lebih kecil atau kurang dari 0.05 .
\end{abstract}

Kata kunci : Produk, Promosi, Keputusan Pembelian, Smartphone 


\section{PENDAHULUAN}

Kondisi perekonomian yang semakin komplek dan perubahan yang demikian cepatnya menyebabkan banyaknya perkembangan pemikiran dan peran pada segala bidang di antaranya adalah pemasaran produk. Untuk perusahaan yang berskala kecil masalah pemasaran produk tidak terlalu rumit, hal itu dikarenakan pihak pimpinan perusahaan masih mampu mengendalikan secara langsung kegiatan operasional perusahaan. Namun untuk perusahaan yang berskala besar di mana kegiatan pengelolahan perusahaan yang semakin kompleks, tentunya pengawasan secara langsung tidak memungkinkan lagi. Diperlukan strategi pemasaran yang kompleks.

Persaingan yang semakin luas menyebabkan harus adanya strategi pemasaran yang dapat membuat usahanya tetap berkembang. Supaya berhasil, perusahaan harus melakukan tugasnya melebihi pesaing dalam memuaskan konsumen sasaran. Merancang strategi pemasaran yang kompetitif dimulai dengan melakukan analisis terhadap pesaing. Dengan cara ini perusahaan dapat menemukan bidang- bidang yang berpotensi untuk dijadikan keunggulan sekaligus mengetahui pula yang menjadi titik kelemahan kompetitifnya. Dengan strategi pemasaran yang andal, perusahaan merancang bauran pemasaran terintregasi yang terdiri atas empat $P$ yaitu Kota Lubuklinggau sendiri, sudah diramaikan dengan berbagai brand sudah akrab ditelinga masyarakat, namun salah satu vendor yang banyak diperbincangkan akhir- akhir ini yaitu vendor asal China, yaitu VIVO. Sebelumnya VIVO bukanlah salah satu vendor yang diunggulkan dibandingkan dengan produk asal China lainnya yaitu Oppo. Namun akhir- akhir ini melalui VIVO Mobile Indonesia (VMI), VIVO meluncurkan produk smartphone yang mengandalkan kamera selfie dan mampu mengambil pasar smartphone di Indonesia yaitu VIVO V5. Secara literatur, seiring degan berkembang zaman, Vendor smartphone haruslah inovatif agar bisa bertahan dalam industri teknologi terutama smartphone yang bisa dibilang dibutuhkan oleh hampir setiap orang. VIVO sendiri mulai 1. Product, 2. Price, 3. Place, dan 4. Promotion (Abdurrahman, 2015:16). Promosi yang dilakukan secara rutin baik melalui media massa dan media elektronik (koran, internet) akanmempengaruhi minat konsumen terhadap produk yang ditawarkan oleh perusahaan tersebut.

Dalam hal penawaran terhadap pasar, produk adalah suatu kunci untuk mengirimkan nilai kepada konsumen. Produk bukan hanya benda yang tampak, namun lebih inklusif lagi seperti fitur layanan, desain, merek dengan kualitas yang prima, dan pengemasan. Kualitas dari sebuah produk memiliki dampak yang signifikan kualitas layanan dari produk itu sendiri (Kotler dan Amstrong 2011). Membangun merek yang memiliki kesan bahwa mereka merupakan merek smartphone untuk anak muda yang fokus pada kualitas suara dan fotografi yang sempura dengan teknologi yang canggih.

Pengamatan awal yang dilakukan peneliti keputusan pembelian untuk pemasaran smartphone VIVO di Kota Lubuklinggau masih sangat ketat, smartphone VIVO harus bersaing dengan smartphone lainnya yang telah memiliki brand dan merek yang cukup terkenal dan diminati oleh masyarakat.

Berdasarkan uraian di atas, maka penelitian ini membahas tentang "Pengaruh Produk dan Promosi terhadap Keputusan Pembelian Smartphone Merek VIVO di Kota Lubuklinggau (Studi Kasus di Konter 3G Cell)".

\section{TINJAUAN PUSTAKA}

\subsection{Pengertian Produk}

Menurut Abdurrahman (2015:71) 
produk adalah segala sesuatu yang dapat ditawarkan ke pasar untuk mendapatkan perhatian, dibeli, dipergunakan atau dikonsumsi dapat dapat memuaskan keinginan kebutuhan.

Menurut Kotler dan Amstrong dalam Abdurrahman (2015:71) produk adalah semua hal yang dapat ditawarkan pada pasar untuk menarik perhatian, akuisisi, penggunaan atau konsumsi yang dapat memuaskan suatu keinginan.

Dari definisi di atas, dapat disimpulkan produk adalah segala sesuatu yang dapat ditawarkan ke pasar untuk mendapatkan perhatian, dibeli, dipergunakan atau dikonsumsi dapat dapat memuaskan keinginan kebutuhan.

\subsection{Pengertian Promosi}

Promosi dapat diartikan sebagai komunikasi awal antara perusahaan dan konsumen serta sebagai salah satu media untuk memperkenalkan produk kepada konsumen agar mengetahui akan keberadaan produk perusahaan tersebut.

Menurut Malau (2017:103) promosi adalah bentuk persuasi langsung melalui penggunaan berbagai insentif yang dapat diatur untuk merangsang pembelian produk dengan segera atau meningkatkan jumlah barang yang dibeli pelanggan.

Menurut Keller dalam Abdurrahman (2015:155) komunikasi pemasaran atau promosi adalah sarana yang digunakan dalam upaya untuk menginformasikan, membujuk, dan mengingatkan konsumen (langsung atau tidak langsung) tentang produk dan merek yang mereka jual.

$$
\text { Berdasarkan pengertian di }
$$

atas, peneliti dapat simpulkan bahwa promosi merupakan penting dalam memasarkan suatu produk sehingga konsumen akan tertarik dan melakukan pembelian terhadap produk tersebut, sehingga suatu promosi perlu dirancang semenarik mungkin dan informasi yang disampaikan dapat dimengerti dengan mudah oleh masyarakat.

\subsection{Pengertian Keputusan Pembelian}

Menurut Kotler dalam Audina

(2017:4), keputusan pembelian adalah suatu tindakan konsumen dalam usaha untuk memenuhi kebutuhannya dalam mengkonsumsi suatu produk yang diikuti oleh kepuasan yang dirasakan oleh konsumen tersebut.

Menurut Setiadi dalam Susanti (2017:282), pengambilan keputusan konsumen adalah proses pengintegrasian yang mengkombinasikan pengetahuan untuk mengevaluasi dua atau lebih perilaku alternatif dan memilih salah satu diantaranya.

Berdasarkan pendapat di atas, dapat disimpulkan pengambilan keputusan konsumen adalah proses pengintegrasian yang mengkombinasikan pengetahuan untuk mengevaluasi dua atau lebih perilaku alternatif dan memilih salah satu diantaranya.

\subsection{Hasil Penelitian yang Relevan}

Menurut penelitian Ipa Audia. 2017, yang berjudul Pengaruh Kualitas Produk dan Harga terhadap Keputusan Pembelian Masker Wajah Mustika Ratu (Studi kasus pada Konsumen Kec. Tembalang Kota Semarang). Penelitian ini memfokuskan pada pengaruh kualitas produk dan harga terhadap keputusan pembelian konsumen di Kec. Tembalang Kota Semarang. Tujuan penelitian ini untuk mengetahui pengaruh kualitas produk dan harga terhadap keputusan pembelian masker wajah Mustika Ratu. Tipe penelitian ini adalah explanatory research. Pengambilan sampel menggunakan teknik non probability sampling dengan metode Purposive sampling. Jumlah sampel yang diambil 100 responden. Penelitian ini dibantu oleh sistem SPSS 16.0. Hasil penelitian menunjukan kualitas produk berpengaruh terhadap keputusan pembelian sebesar 21,5\%. Harga berpengaruh terhadap keputusan pembelian sebesar $29,7 \%$. 
Secara simultan kualitas produk dan harga berpengaruh terhadap keputusan pembelian sebesar 35,6\%. Perhitungan Uji F menunjukkan terdapat terdapat pengaruh positif antara kualitas produk dan harga terhadap keputusan pembelian. Semakin baik kualitas produk dan persepsi konsumen terhadap harga semakin tinggi keputusan pembelian masker wajah Mustika Ratu. Selain itu harga mempunyai pengaruh paling dominan dengan nilai keofisien regresi 0,715. Saran dalam penelitian ini adalah meningkatkan kualitas produk baik kemasan, fungsi dan keragaman ukuran produk masker wajah Mustika Ratu. Selain itu dari sisi harga, kesesuaian harga dengan kualitas dan manfaat produkharus diperbaiki danditingkatkan.

Menurut penelitian Heni. 2017, yang berjudul "Pengaruh Bauran Pemasaran Terhadap Keputusan Pembelian Smartphone Merek Samsung Pada Mahasiswa Universitas Alkhairaat Palu". Tujuan penelitian ini untuk mengetahui dan menganalisis pengaruh bauran pemasaran terhadap keputusan pembelian smartphone merek Samsung pada mahasiswa Universitas Alkhairaat Palu. Jenis penelitian yang digunakan adalah deskriptif kausal, menggunakan teknik penarikan sampel Purposive Sampling, dengan jumlah sampel 60 responden. Metode analisis yang digunakan yaitu Analisis Regresi Linear Berganda dengan menggunakan bantuan dari program komputer SPSS for Windows Release 16,0. Uji hipotesis yang digunakan mempunyai taraf signifikansi $\alpha=0,05$ dan untuk uji reliabilitas menggunakan nilai koefisien croanbach alpha dengan nilai batas koefisien $\alpha=0,60$ Hasil penelitian ini menunjukkan bahwa secara simultan bauran pemasaran berpengaruh signifikan terhadap keputusan pembelian, dengan nilai sig 0,000. Secara parsial dengan standar $\alpha=$ 0,05 diperoleh hasil penelitian Produk (X1), Harga (X2), Tempat (X3), dan
Promosi (X4) berpengaruh signifikan terhadap keputusan pembelian dengan nilai sig masing-masing sebesar 0,007, 0,000. 0,012, dan 0,000. Keempat variabel ini berpengaruh sebesar 0,876 atau $87,6 \%$ terhadap keputusan pembelian sedangkan sisanya sebesar $12,4 \%$ dipengaruhi oleh variabel lain.

Menurut penelitian Zen Zen Guisi. 2018, yang berjudul The Effect Of Marketing Mixed Strategy on Marketing Performance and Competitive Excellence In Shopping Mall In Bandung and Denpasar Regency. The objective of this study is to identify the effect of marketing mixed strategy on marketing performance and competitive excellence at shopping mall in Badung and Denpasar. The data were collected by distributing questionnaires to 43 respondents taken by slovin formula method. Respondents were managers and leaders of shopping malls in Badung and Denpasar regencies. Data were analyzed by Partial Least Square (PLS) analysis method. Measurement of research variables is done by using Likert scale to test the research instrument with validity and reliability test. The results showed that to achieve marketing performance can be made through the use of $7 P$ marketing mixed strategy aimed at achieving marketing performance with the elements of product, place, price, promotion, process, people and physical. While marketing performance has a positive and significant impact on competitive advantage, where to achieve marketing performance with elements of sales growth, customer growth and sales volume. Furthermore marketing mixed strategy has a positive effect on competitive advantage but not significant. Suggestions for further research, it needs more concern to analyze the shopping mall in Bali so that the scope becomes wider for generalization in a wider area. 


\section{METODOLOGI PENELITIAN}

\subsection{Rancangan Penelitian}

Penelitian ini Berjudul pengaruh produk dan promosi terhadap keputusan pembelian smartphone merek VIVO di Kota Lubuklinggau. Langkah awal dalam penelitian ini adalah merumuskan masalah penelitian. Selanjutnya membuat instrumen penelitian berupa Angket, wawancara. penelitian ini menggunakan jenis penelitian Deskripftif Kuantitatif.

\subsection{Variabel Penelitian dan Definisi Operasional Variabel}

Definisi operasional dalam penelitian ini dapat dilihat pada tabel berikut :

\section{Tabel 1}

Variabel Penelitian dan Definisi Operasional Variabel

\begin{tabular}{|c|c|c|c|}
\hline Variabel & $\begin{array}{c}\text { Definisi } \\
\text { Operasional }\end{array}$ & Indikator & $\begin{array}{c}\text { Skala } \\
\text { Pengukuran }\end{array}$ \\
\hline Produk (X1) & $\begin{array}{l}\text { Produk adalah segala } \\
\text { sesuatu yang dapat } \\
\text { ditawarkan ke pasar } \\
\text { untuk mendapatkan } \\
\text { perhatian, dibeli, } \\
\text { Dipergunakan atau } \\
\text { dikonsumsi dapat } \\
\text { dapat memuaskan } \\
\text { keinginan } \\
\text { kebutuhan. } \\
\text { Abdurrahman } \\
(2015: 71)\end{array}$ & $\begin{array}{ll}\text { a. } & \text { Kualitas } \\
\text { barangnya baik. } \\
\text { besain } \\
\text { barangny } \\
\text { abaik. } \\
\text { c. } \\
\text { Barangbar } \\
\text { u } \\
\text { dapat ditambah } \\
\text { kan jika } \\
\text { diperlukan. } \\
\text { Sunyoto } \\
(2015: 82)\end{array}$ & Likert \\
\hline Promosi (X2) & $\begin{array}{l}\text { Promosi adalah } \\
\text { bentuk persuasi } \\
\text { langsung } \\
\text { melalui } \\
\text { penggunaan } \\
\text { berbagai dapat } \\
\text { insentif yang } \\
\text { diatur untuk } \\
\text { merangsang } \\
\text { pembelian } \\
\text { produk dengan } \\
\text { segera atau } \\
\text { meningkatkan } \\
\text { jumlah barang } \\
\text { yang dibeli } \\
\text { pelan ggan. } \\
\text { Menurut } \\
\text { Mala u } \\
\text { (2017:103) }\end{array}$ & \begin{tabular}{|ll} 
a. & Customer \\
b. & Trade \\
& promotion \\
c. & Sales- force \\
& promotion \\
d. & Business \\
& Promotion \\
& (menurut \\
& Malau \\
& $2017: 104)$
\end{tabular} & Likert \\
\hline
\end{tabular}

\begin{tabular}{|c|c|c|c|}
\hline $\begin{array}{l}\text { Keputusan } \\
\text { Pembelian (Y) }\end{array}$ & $\begin{array}{l}\text { Keputusan } \\
\text { pembelian } \\
\text { adalah suatu } \\
\text { tindakan } \\
\text { konsumen } \\
\text { dalam usaha } \\
\text { untuk } \\
\text { memenuhi } \\
\text { kebutuhannya } \\
\text { dalam } \\
\text { mengkonsumsi } \\
\text { suatu produk } \\
\text { yangdiikutioleh } \\
\text { kepuasan yang } \\
\text { dirasakan oleh } \\
\text { konsumen } \\
\text { tersebut. } \\
\text { keputusan } \\
\text { pembelian } \\
\text { adalah suatu } \\
\text { tindakan } \\
\text { konsumen } \\
\text { dalam usaha } \\
\text { untuk } \\
\text { memenuhi } \\
\text { kebutuhannya } \\
\text { dalam } \\
\text { mengkonsumsi } \\
\text { suatu produk } \\
\text { yangdiikutioleh } \\
\text { kepuasan yang } \\
\text { dirasakan oleh } \\
\text { konsumen } \\
\text { tersebut. } \\
\text { Kotler dalam Ipa } \\
\text { Audina (2017:4). }\end{array}$ & 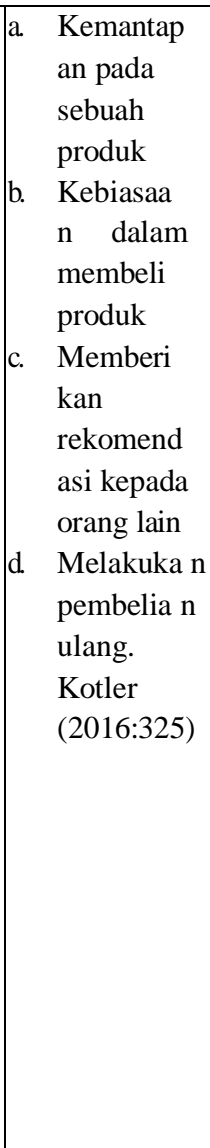 & Likert \\
\hline
\end{tabular}

\subsection{Populasi dan Sampel}

\section{Populasi}

Populasi adalah wilayah

Generalisasi yang terdiri atas; obyek/subyek yang mempunyai kuantitas dan karateristik tertentu yang ditetapkan oleh peneliti untuk dipelajari dan kemudian ditarik kesimpulannya (Sugiyono, 2015:148). Dengan demikian yang menjadi populasi dalam penelitian ini adalah seluruh pengguna Smartphone VIVO di Lubuklinggau yang membeli produk smartphone VIVO pada bulan Maret 2019 pada Ratu 3G Lubuklinggau sebanyak 40 orang.

\section{Sampel}

Penentuan sampel dengan menggunakan teknik Cluster sampling (area sampling). Menurut Sugiyono (2015:153) Cluster sampling (area sampling) adalah teknik penentuan sampel bila objek yang akan diteliti atau sumber data sangat luas, misalnya penduduk suatu negara, 
propinsi, kabupaten atau kota, jadi sehubungan dengan penelitian ini sampel pada penelitian ini berjumlah 40 orang yang tinggal di Lubuklinggau dan menggunakan smartphone VIVO yang pembeliannya dilakukan pada Ratu 3G Lubuklinggau pada bulan Maret.

\subsection{Instrumen Penelitian}

Instrumen penelitian yang digunakan dalam penelitian ini adalah kuesioner atau angket dengan menggunakan skala likert. Berikut jumlah instrumen penelitian:

Tabel 2

Instrumen Variabel Penelitian

\begin{tabular}{|l|l|c|}
\hline No & \multicolumn{1}{|c|}{ Variabel } & Jumlah Soal \\
\hline 1 & Produk $\left(\mathrm{X}_{1}\right)$ & 9 \\
\hline 2 & Promosi $\left(\mathrm{X}_{2}\right)$ & 12 \\
\hline 3 & Kinerja Pegawai $(\mathrm{Y})$ & 12 \\
\hline \multicolumn{2}{|l|}{ Jumlah Soal } & 55 tem \\
\hline
\end{tabular}

\section{Uji Coba Instrumen}

a. Uji Validitas

Uji validitas adalah suatu ukuran yang menunjukkan tingkat-tingakt kevalidan atau kesahihan suatu instrumen. Arikunto (2013: 213). Uji Coba validitas dilakukan di konter Tio Cell 3 Lubuklinggau.

$r_{x y}=\frac{N\left(\sum X Y\right)-\left(\sum X\right)\left(\sum Y\right)}{\sqrt{\left\{N\left(\sum X^{2}\right)-\left(\sum X\right)^{2}\right\}\left\{N\left(\sum Y^{2}\right)-\left(\sum Y\right)^{2}\right\}}}$

Keterangan:
$r_{x y}$ : Koefisien korelasi antara $X$ dan $\mathrm{Y}$
$\sum X Y$ : Jumlah perkalian antara
$\mathrm{X}$ dan $\mathrm{Y} \mathrm{N}$ : Banyaknya sampel
$\mathrm{X}$ : Skor butir soal
Y : Skor total

\section{b. Uji Reliabilitas}

Menurut Arikunto (2013:178) "Reliabilitas menunjuk pada pada satu pengertian bahwa sesuatu instrumen cukup dapat dipercaya untuk digunakan sebagai alat pengumpul data karena instrumen tersebut sudah baik". Untuk mengetahui reliabilitas instrument tes digunakan rumus sebagai berikut:

$$
r_{11}=\left(\frac{n}{(n-1)}\right)\left(1-\frac{\sum s_{1}{ }^{2}}{s_{1}{ }^{2}}\right)
$$

Keterangan:

$$
\begin{array}{ll}
\mathrm{r} 11 & \begin{array}{l}
\text { : Reliabilitas instrument } \\
\mathrm{n}
\end{array} \\
\sum s^{2} & \begin{array}{l}
\text { : Banyaknya butir pertanyaan } \\
\text { atau banyaknya soal. }
\end{array} \\
& \text { Jumlah varisans skor tiap butir } \\
\text { soal } s_{1}{ }^{2} & : \text { Varians skor total }
\end{array}
$$

Klasifikasi untuk menginterfresentasi reliabilitas suatu tes, yaitu:

\begin{tabular}{|c|c|c|c|l|}
\hline & $\mathrm{r} 11$ & $\leq$ & 0,20 & $\begin{array}{l}\text { Reliabilitas } \\
\text { sangat rendah }\end{array}$ \\
\hline 0,20 & $<\mathrm{r} 11$ & $\leq$ & 0,40 & $\begin{array}{l}\text { Reliabilitas } \\
\text { rendah }\end{array}$ \\
\hline 0,40 & $<\mathrm{r} 11$ & $\leq$ & 0,60 & $\begin{array}{l}\text { Reliabilitas } \\
\text { sedang }\end{array}$ \\
\hline 0,60 & $<\mathrm{r} 11$ & $1 \leq$ & 0,80 & Reliabilitas tinggi \\
\hline 0,80 & $<\mathrm{r} 11$ & $\leq$ & 1,00 & $\begin{array}{l}\text { Reliabilitas } \\
\text { sangat tinggi }\end{array}$ \\
\hline
\end{tabular}

\section{Uji Asumsi Klasik \\ a. Uji Normalitas}

Salah satu uji persyaratan yang harus dipenuhi dalam penggunaan analisis parametik yaitu uji kenormalan data populasi. tujuan dilakukannya uji normalitas yaitu untuk mengetahui apakah data berdistribusi normal maka dapat dipakai dalam statistik parametik dan data tersebut dapat mewakili populasi. Pengujian dilakukan terhadap semua pertanyaan yang telah dinyatakan valid dan reliabel. Cara yang bisa dipakai untuk melakukan uji normalitas yaitu menggunakan One Sample Kolmogrof Smirnov Test (Syofian, 2014:153).

\section{b. Uji Liniearitas}

Uji linearitas bertujuan untuk mengetahui apakah dua variabel mempunyai hubungan yang linear atau tidak secara signifikan. Dua variabel dikatakan memiliki hubungan yang linear apabila nilai signifikan (linearity) kurang dari 0,05, dengan demikian data kelompok variabel $\mathrm{X}$ 
dengan kelompok variabel $\mathrm{Y}$ berpola linear (Syofian, 2014:178).

\subsection{Teknik Analisis Data}

\section{Regresi Linear Sederhana}

Dengan tujuan untuk meneliti sejauh mana pengaruh produk, dan promosi (independent) terhadap keputusan pembelian sebagai variabel terikat (dependen), maka regresi yang digunakan adalah. sederhana:

Persamaan umum regresi linier

$r=\frac{n \cdot(\Sigma X Y)-(\Sigma X)(\Sigma Y)}{\sqrt{\left\{n \cdot \Sigma X^{2}-(\Sigma X)^{2}\right\} \cdot\left\{n \cdot \Sigma Y^{2}-(\Sigma Y)^{2}\right\}}}$ (Riduwan, 2014; 227)
$Y=\quad a+b X \ldots . .(1) \quad$ Sumber: Arikunto
$(2014 \cdot 301)$

Dimana:

$\mathrm{Y}=$ Keputusan pembelian

$\mathrm{X}=$ Produk, promosi

$\mathrm{A}=$ Konstanta

$\mathrm{B}=$ Koefisien regresi

\section{Koefisien Korelasi}

Adalah mencari hubungan variabel bebas dengan variabel terikat dan data berbentuk interval dan ratio.

Dimana $r=$ Koefisien korelasi Koofisien korelasi dan koefisien yang dihasilkan, dapat berpedoman pada ketentuan berikut :

\begin{tabular}{|c|l|}
\hline $0.00-0.199$ & Sangat Rendah \\
\hline $0.20-0.399$ & Rendah \\
\hline $0.40-0.599$ & Sedang \\
\hline $0.60-0.799$ & Kuat \\
\hline $0.80-1.00$ & Sangat Kuat \\
\hline
\end{tabular}

Sumber : Ridwan, 2014:228)

\section{Uji t}

Untuk membuktikan variabel independen berpengaruh secara signifikan terhadap variabel dependen.

$t_{\text {mang }}=\frac{r \sqrt{n-2}}{\sqrt{n-r^{2}}} \quad$ (Sugiyono, 2015:195)

Dimana:

$\mathrm{T}=$ nilai $\mathrm{t}$ hitung

$\mathrm{R}=$ koefisien korelasi

$\mathrm{N}=$ Jumlah responden

\section{Regresi Linear Berganda}

Dengan tujuan untuk mengetahui pengaruh produk dan promosi (independen) terhadap keputusan pembelian sebagai variable terikat (dependen), maka regresi yang digunakan adalah persamaan umum regresi linier berganda:

$\mathrm{Y}=\mathrm{a}+\mathrm{b}_{1} \mathrm{X}_{1}+\mathrm{b}_{2} \mathrm{X}_{2}$

(Arikunto,2014:339)

Keterangan:

Y : Keputusan pembelian

a : Konstanta

b1 : Koefiseien korelasi produk

$b_{2} \quad$ : Koefesien korelasi promosi

$\mathrm{X}_{1}$ : Produk

$\mathrm{X}_{2}$ : Promosi

\section{Koefisien Determenasi (R2)}

Untuk menghitung pengaruh saling ketergantugan variable ltersebut harus diuji besar kecilnya dengan menghitung koefesien determinasi. (Sugiyono dalam Desi, 2015:24).

$$
\mathrm{R}^{2}=\frac{b_{1} \sum X_{1} Y+b_{2} \sum X_{2} Y}{\sum Y^{2}}
$$

Dimana:

R2 : Koefisien determinasi

b1 :Koefisien

korelasi produk b2 :Koefisien

korelasi promosi X1 : Produk

X2 : Promosi

Y : Keputusan pembelian

\section{Uji Signifikan Simultan (Uji F)}

Uji $F$ adalah pengujian regresi secara simultan atau serentak antara variable independen terhadap variable dependen.

$$
\begin{aligned}
& \text { Freg }= R^{2}(n-m-1) \\
& M\left(1-R^{2}\right)
\end{aligned}
$$

Keterangan :

$\mathrm{R}^{2}$ : Koefisien determinasi

$\mathrm{n}$ : Banyaknya sampel

m: BanyaknyaVarians 
Apabila hasil perhitungan Fhitung > Ftabel maka Ho ditolak sehingga dapat dikatakan bahwa variabel bebas regresi dapat menerangkan variabel terikat secara serentak. Sebaliknya jika Fhitung < Ftabel maka Ho diterima dengan demikian dapat dikatakan bahwa variabel bebas dari model regresi berganda tidak mampu menjelaskan variabel terikat.

\section{HASIL DAN PEMBAHASAN}

\subsection{Hasil Penelitian}

\section{Uji Asumsi Klasik}

Peneliti menggunakan statistik untuk pengolahan datanya. Dikarenakan teknik analisis data menggunakan analisis regresi berganda, maka peneliti melakukan uji asumsi klasik dengan menggunakan uji normalitas dan uji multikolinear. Berikut adalah uji asumsi klasik variabel produk (X1), promosi (X2), dan keputusan pembelian (Y) dengan menggunakan SPSS 20.

\section{Uji Normalitas}

Uji Normalitas dimasudkan untuk melihat tingkat kenormalan data, berikut hasil uji normalitas;

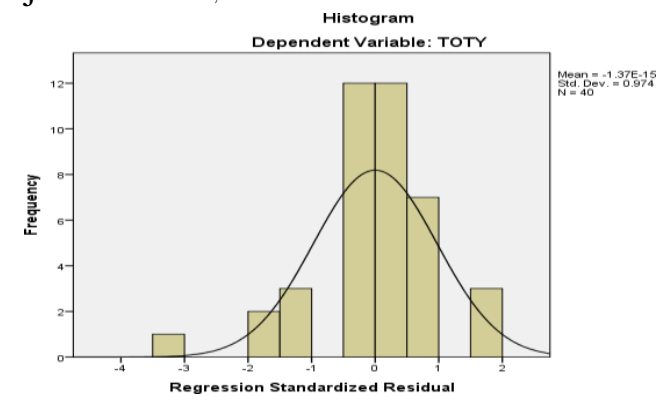

Gambar 2

\section{Uji Normalitas (Histogram)}

Pada gambar 2 Uji normalitas (histogram) tampak bahwa tiap data menyebar ke seluruh daerah normal. Daerah normal itu sendiri adalah daerah yang berada di bawah kurva tersebut berbentuk seperti lonceng terbalik. Jadi dikatakan data berdistribusi normal. Data berdistribusi normal juga terbukti pada autput gambar 3 hasil Normal P-P Plot. Titik- titik menyebar sepanjang garis regresi. Hal tersebut mengartikan sebaran datanya merata sehingga dapat dihasilkan $\mathrm{Y}$ yang merata pula pada garis regresi.

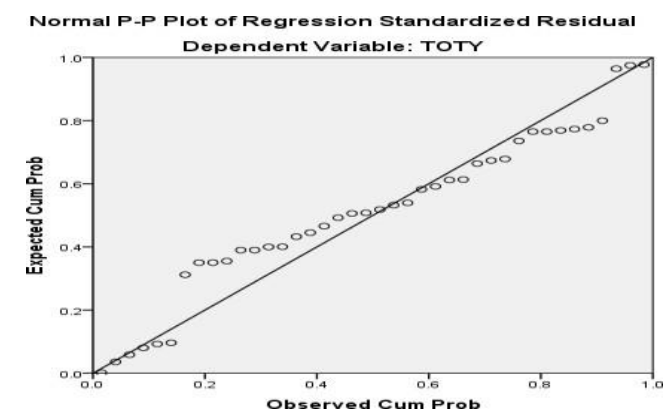

Gambar 3

\section{Normal P-P Plot of Regression Standardized Residual Dependent Variable :}

Dari analisis kurva dapat dilihat bahwa data menyebar disekitar diagram dan mengikuti model regresi sehingga dapat disimpulkan bahwa data yang diolah merupakan data yang berdistribusi normal sehingga uji normalitas terpenuhi.

Pada uji Kolmogorov-Smirnov dapat ditentukan juga data berdistribusi normal atau tidak. Data dikatakan normal jika nilai signifikansi $>0,05$. Berikut ini menggunakan perhitungan tabel:

\section{Tabel 3}

One Sample Kolmogorov-Smirnov Test

\begin{tabular}{|c|c|c|c|c|}
\hline \multicolumn{5}{|c|}{ One-Sample Kolmogorov-Smirnov Test } \\
\hline & & TOTX1 & TOTX2 & TOTY \\
\hline \multicolumn{2}{|l|}{$\mathrm{N}$} & 40 & 40 & 40 \\
\hline \multirow{2}{*}{ Normal Parameters ${ }^{a, b}$} & Mean & 33.68 & 44.98 & 46.53 \\
\hline & Std. Deviation & 3.983 & 6.608 & 4.712 \\
\hline \multirow{3}{*}{$\begin{array}{l}\text { Most Extreme } \\
\text { Differences }\end{array}$} & Absolute & 180 & .195 & .200 \\
\hline & Positive & .114 & .098 & .098 \\
\hline & Negative & -180 & :195 & -200 \\
\hline \multicolumn{2}{|l|}{ Kolmogorov-Smirnov Z } & 1.140 & 1.236 & 1.267 \\
\hline \multicolumn{2}{|l|}{ Asymp. Sig. (2-tailed) } & 148 & .094 & .081 \\
\hline
\end{tabular}

Hasil pada tabel 7 di atas menunjukkan nilai sig untuk variabel produk memiliki nilai 0,148 , sig untuk variabel promosi sebesar 0,096, sedangkan sig untuk variabel keputusan pembelian memiliki nilai 0,081. Ketiga nilai sig yang dihasilkan 
melebihi atau lebih besar dari 0,05, maka dapat dikatakan variabel produk, promosi dan keputusan pembelian memiliki distribusi data yang normal.

\section{Uji Lineritas}

Uji linearitas bertujuan untuk mengetahui apakah ketiga variabel mempunyai hubungan yang linear atau tidak secara signifikan. Uji ini biasanya digunakan sebagai prasyarat dalam analisis korelasi atau regresi linear. Untuk menganalisis menggunakan hasil data output SPSS 20 dapat dilihat pada tabel 8 dan tabel 9 anova tabel seperti berikut ini:

\section{Tabel 4}

Produk terhadap Keputusan Pembelian

\begin{tabular}{|c|c|c|c|c|c|c|c|}
\hline \multicolumn{8}{|c|}{ ANOVA Table } \\
\hline & & & $\begin{array}{l}\text { Sum of } \\
\text { Squares }\end{array}$ & df & $\begin{array}{l}\text { Mean } \\
\text { Square }\end{array}$ & $F$ & Sig. \\
\hline \multirow{6}{*}{$\begin{array}{l}\text { TOTY* } \\
\text { TOTX1 }\end{array}$} & & (Combined) & 668.275 & 11 & 60.752 & 8.604 & .000 \\
\hline & Between & Linearity & 585.339 & 1 & 585.339 & 82.901 & .000 \\
\hline & Groups & Deviation from & & & & & \\
\hline & & Linearity & & & & & \\
\hline & Within Gr & & 197.700 & 28 & 7.061 & & \\
\hline & Total & & 865.975 & 39 & & & \\
\hline
\end{tabular}
membuktikan bahwa hubungan yang terjadi antara variabel bebasnya dengan variabel terikatnya bersifat linear.

\section{Tabel 5}

\section{Promosi terhadap Keputusan Pembelian}

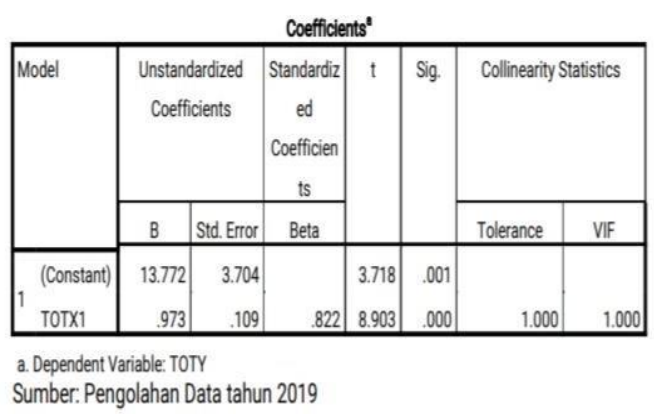

Hasil uji linearitas diatas membuktikan bahwa hubungan yang terjadi antara variabel bebasnya dengan variabel terikatnya bersifat linear. Pada tabel 9 yang menggambarkan uji hubungan bersifat linear antara promosi dan keputusan pembelian nilai sig. Pada kolom baris Linearity sebesar 0,000 pabila nilai sig. $<0,05$ mengartikan hubungan prediktor dan dependen variabel bersifat linear, maka kedua nilai sig. Pada anova tabel memenuhi syarat linear.

\section{Hasil Analisis Data \\ a. Regresi Liear Sederhana}

Model regresi linear sederhana digunakan untuk melihat bagaimana pengaruh produk dan promosi berpengaruh signifikan terhadap keputusan pembelian smartphone merek VIVO di Kota Lubuklinggau.

Rumus yang digunakan adalah: $\mathrm{Y}=\mathrm{a}+\mathrm{bX}$

\section{Tabel 6}

Produk terhadap Keputusan Pembelian

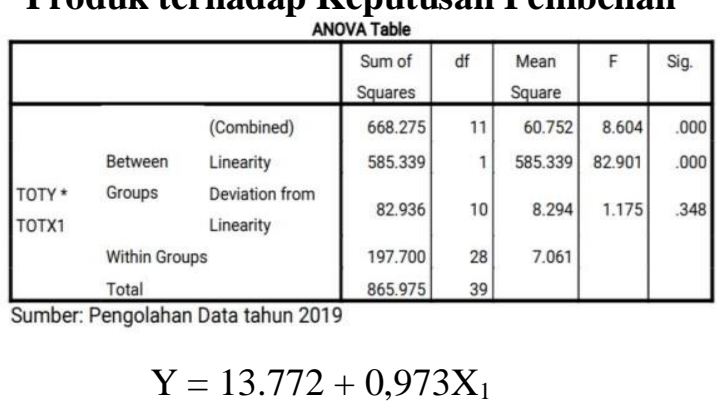

Dari persamaan nilai estimasi fungsi regresi di atas terlihat bahwa nilai konstanta yang diperoleh 13.772. Hal ini menggambarkan bahwa tanpa dipengaruhi oleh variabel (X) maka keputusan pembelian (Y) adalah sebesar 13.772. Nilai koefesien regresi mewakili variabel pendidikan yang diperoleh sebesar 0.973 menunjukkan bahwa setiap perubahan pada produk maka keputusan pembelian akan berubah berbanding lurus, yakni sebesar 0,973 dengan asumsi variabel bebas lainnya konstan. oleh variabel (X) maka keputusan pembelian (Y) adalah sebesar 23.271. Nilai koefesien regresi mewakili variabel promosi yang diperoleh sebesar 0.517 menunjukkan bahwa setiap perubahan pada promosi maka keputusan pembelian akan berubah berbanding lurus, yakni sebesar 0,517 dengan asumsi variabel bebas lainnya konstan. 


\section{b. Koefisien Korelasi}

Pengujian kontribusi pengaruh dari variabel bebas $(\mathrm{X})$ terhadap variabel tidak bebas (Y), dapat dilihat dari koefisien korelasi dimana $0<r^{2}<1$. Hal ini menunjukkan jika $r^{2}$ semakin dekat dengan 1, maka pengaruh variabel bebas (X) terhadap variabel tidak bebas (Y) semakin kuat. Sebaliknya jika $r^{2}$ semakin dekat pada 0 maka pengaruh variabel bebas (X) terhadap variabel tidak bebas $(\mathrm{Y})$ semakin lemah.

\section{Tabel 7}

Model Summary

Model Summary

\begin{tabular}{l|c|c|c|c|}
\hline Model & $R$ & $\begin{array}{c}R \\
\text { Square }\end{array}$ & $\begin{array}{c}\text { Adjusted R } \\
\text { Square }\end{array}$ & \multicolumn{1}{c|}{$\begin{array}{l}\text { Std. Error of the } \\
\text { Estimate }\end{array}$} \\
\hline 1 & $.869^{\mathrm{a}}$ & .754 & .741 & 2.397 \\
\hline
\end{tabular}
a. Predictors: (Constant), TOTX2, TOTX1
b. Dependent Variable: TOTY
Sumber; Hasil Olahan Data, tahun 2019

Berdasarkan hasil uji koefisien korelasi pada tabel 12 yang diperoleh dari hasil pengolahan dengan SPSS 20 for windows, variabel produk (X1), promosi (X2), terhadap keputusan pembelian (Y), nilai koefisien korelasi sebesar 0,869 berada pada interval koefisien $0.80-1.00$, yang berarti hubungan antara variabel produk, promosi terhadap keputusan pembelian menunjukkan hubungan yang sangat kuat dan nilai korelasi positif artinya korelasi atau hubungan produk, promosi terhadap keputusan pembelian searah.

\section{c. Uji t Parsial}

\section{Pengaruh Produk terhadap} Keputusan Pembelian Smartphone Merek VIVO di Kota Lubulinggau

Untuk melihat pengaruh parsial dari masingmasing variabel bebas terhadap variabel terikat dapat dijelaskan dengan menggunakan uji t, berikut hasil perhitungan uji t;
Tabel 8

Hasil Ujit $X_{1}$ dan Y

\begin{tabular}{|c|r|r|}
\hline Model & \multicolumn{1}{|c|}{$t$} & \multicolumn{1}{|c|}{ sig } \\
\hline 1 (constant) & 3.718 & .000 \\
Produk & 8.903 & .000 \\
\hline
\end{tabular}

a. Dependent variabel; produk

\section{Sumber : Hasil pengolahan data, Tahun 2019}

Berdasarkan rekapitulasi hasil uji t di atas, dapat dijelaskan bahwa variabel produk terhadap keputusan pembelian, hal tersebut ditunjukkan dari nilai thitung lebih besar dari ttabel, yaitu $8.903>2,021$ dengan $\mathrm{dk}=40(40-2=38)$ dan tingkat signifikan sig $=0,000$, hal ini berarti bahwa secara parsial variabel produk memiliki pengaruh yang signifikan terhadap Keputusan Pembelian Smartphone Merek VIVO di Kota Lubuklinggau. Hal ini menunjukkan hipotesis pada penelitian ini terbukti atau hipotesis diterima.

\section{Pengaruh Promosi terhadap Keputusan Pembelian Smartphone Merek VIVO di Kota Lubulinggau}

Tabel 9

Hasil Uji $X_{2}$ dan $Y$

\begin{tabular}{|l|r|r|}
\hline Model & \multicolumn{1}{|c|}{$\mathrm{t}$} & \multicolumn{1}{c|}{ sig } \\
\hline 1 (constant) & 6.428 & .000 \\
Promosi & 6.490 & \\
\hline
\end{tabular}

a. Dependent variabel; promosi

Sumber : Hasil pengolahan data, Tahun 2019

Berdasarkan rekapitulasi hasil uji t di atas, dapat dijelaskan bahwa variabel promosi terhadap keputusan pembelian, hal tersebut ditunjukkan dari nilai thitung lebih besar dari ttabel, yaitu $6.490>2,021$ dengan $\mathrm{dk}=40(40-2=38)$ dan tingkat signifikan sig $=0,000$, hal ini berarti bahwa secara parsial variabel mempengaruhi keputusan pembelian sebesar 0,355 satuan. 


\section{d. Koefisien Determinasi}

Berdasarkan pengolahan hasil data di atas, diketahui nilai dari koefisien determinasi yang dapat digunakan untuk mengetahui besarnya proporsi variabel independen dalam menjelaskan variasi perubahan variabel dependen, nilai koefisien korelasi merupakan sebuah nilai untuk mengukur kekuatan pengaruh antara variabel respons keputusan pembelian dengan semua variabel penjelas, $\mathrm{X} 1, \mathrm{X} 2$ produk dan promosi. Dengan cara memasukkan nilai rekapan atau tabulasi data tersebut ke rumus koefisien korelasi dan determinasi dengan menggunakan SPSS For Windows 20.0 dengan hasil sebagai berikut :

Tabel 10

Koefisien Determinasi Model Summary ${ }^{b}$

\begin{tabular}{|l|c|r|r|r|}
\hline Model & \multicolumn{1}{|c|}{ Model Summary $^{b}$} & $\begin{array}{c}\text { R } \\
\text { Square }\end{array}$ & Adjusted R Square & Std. Error of the Estimate \\
\hline 1 & $.869^{\mathrm{a}}$ & .754 & .741 & 2.397 \\
\hline
\end{tabular}

a. Predictors: (Constant), TOTX2, TOTX1

b. Dependent Variable: TOTY

Sumber; Hasil Olahan Data, tahun 2019

Dari hasil perhitungan diperoleh besarnya nilai koefisien determinasi $\left(\mathrm{R}^{2}\right)$ sebesar 0,754 yang berarti bahwa $75,4 \%$ baiknya produk dan promosi dapat dijelaskan oleh indikator-indikator yang ada di dalam produk dan promosi, sedangkan sisanya sebesar $(100 \%$ $75,4 \%=24,6 \%)$ dijelaskan oleh sebabsebab yang lain seperti distirbusi, harga dan lain-lain.

\section{e. Uji F}

Untuk mengetahui produk dan promosi berpengaruh signifikan terhadap Keputusan Pembelian Smartphone Merek VIVO di Kota Lubuklinggau, maka digunakan uji $\mathrm{F}$ dengan menggunakan SPSS For Windows 20.0 hasil sebagai berikut:
Tabel 11

Hasil Uji F

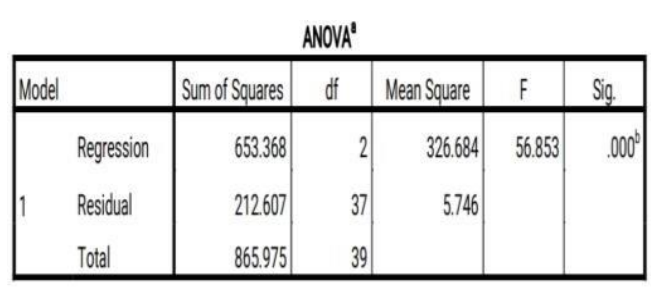

a. Dependent Variable: TOTY

b. Predictors: (Constant), TOTX2, TOTX1

\section{Sumber, hasil pengolahan data, tahun 2019}

Berdasarkan hasil pengolahan data diketahui nilai $\mathrm{f}_{\text {hitung }}$ sebesar 56.853 dengan tingkat signifikansinya 0.000 . Dikarenakan nilai $f_{\text {hitung }}$ sebesar $=56.853$ lebih besar dari nilai $\mathrm{f}_{\text {tabel }}=3,25$ dan probabilitas (sig. 0.000) lebih kecil atau kurang dari 0.05, maka Ha : diterima dan H0 : ditolak, yang berarti ada pengaruh yang signifikan produk dan promosi secara bersama-sama terhadap keputusan pembelian Smartphone Merek VIVO di Kota Lubuklinggau.

\subsection{Pembahasan}

1. Pengaruh Produk terhadap Keputusan Pembelian Smarthphone VIVO di Kota Lubuklinggau

Berdasarkan rekapitulasi hasil uji t, dapat dijelaskan bahwa variabel produk terhadap keputusan pembelian, hal tersebut ditunjukkan dari nilai thitung lebih besar dari ttabel, yaitu 8.903> 2,021 dengan dk (40$2=38$ ) dan tingkat signifikan sig $=0,000$, hal ini berarti bahwa secara parsial variabel produk memiliki pengaruh yang signifikan terhadap Keputusan Pembelian Smartphone Merek VIVO di Kota Lubuklinggau. Hal ini menunjukkan hipotesis pada penelitian ini terbukti atau hipotesis diterima .

Sesuai dengan indikator produk menurut Sunyoto (2015:82), kualitas barangnya baik, desain barangnya baik, dan barang baru dapat ditambahkan jika diperlukan. Dari hasil perhitungan pengolahan data kuisioner, bahwa responden 
setuju kualitas produk harus baik. Kualitas produk menentukan keputusan pembelian produk oleh konsumen. Kualitas produk yang baik dapat bersaing di pasaran. Desain HP VIVO harus menarik konsumen. Pendistribusian barang harus menjangkau semua lokasi penjualan produk VIVO. Produk yang kualitas baik akan banyak diminati masyarakat. Masyarakat yang sudah mengetahui kualitas produk akan melakukan pembelian ulang.

\begin{tabular}{lcr}
\multicolumn{2}{c}{ Kualitas produk tidak dapat } \\
dilepaskan dari & faktor & yang \\
mempengaruhinya. & Sejalan & dengan \\
pendapat Menurut & Sunyoto & $(2015: 90)$
\end{tabular}
faktor-faktor yang mempengaruhi pemasaran produk adalah:

a. Kebutuhan dan keinginan konsumen terus dipantau agar memperoleh informasi tentang hal-hal yang harus dilakukan untuk menciptakan gagasangagasan jitu.

b. Para ilmuwan merupakan sumber ide yang menarik, tetapi diperlukan seleksi yang teliti.

c. Pesaing yang telah menciptakan dan meluncurkan ide-ide baru serta produkproduk yang diciptakan dan diluncurkan pesaing tersebut perlu diinovasi,

d. Sumber ide akan dapat dijadikan suatu produk baru yang memiliki keunggulan bersaing.

\section{Pengaruh Promosi terhadap Keputusan Pembelian Smartphone VIVO di Kota Lubuklinggau}

Berdasarkan rekapitulasi hasil uji t, dapat dijelaskan bahwa variabel promosi terhadap keputusan pembelian, hal tersebut ditunjukkan dari nilai thitung lebih besar dari ttabel, yaitu $6.490>2,021$ dengan $\mathrm{dk}$ $(40-2=38)$ dan tingkat signifikan sig $=0,10$, hal ini berarti bahwa secara parsial variabel promosi memiliki pengaruh yang signifikan terhadap Keputusan Pembelian Samrtphone Merek VIVO di Kota Lubuklinggau. Hal ini menunjukkan hipotesis pada penelitian ini terbukti atau hipotesis diterima.

Sesuai dengan indikator promosi menurut Malau (2017:104) customer promosi, trade promotion, sales-force promotion, business promotion. Dari hasil perhitungan pengolahan data kuisioner, bahwa responden setuju Kemasan Smartphone VIVO harus menarik konsumen. Merk suatu produk mempengaruhi keputusan konsumen untuk membeli produk tersebut. Harga Amartphone VIVO cukup terjangkau oleh konsumen. Promosi dengan cara fiyring dan dance cukup efektif. Lokasi tempat penjualan suatu produk menentukan banyaknya jumlah penjualan. Promosi penjualan harus dilakukan oleh suatu perusahaan yang akan memasarkan produknya. Media promosi dapat dilakukan lewat iklan. Iklan yang digunakan harus dikemas semenarik mungkin.

Sejalan dengan pendapat Supardi Lee (2016:2), fungsi dari promosi adalah sebagai berikut:

\section{Fungsi Pengenalan}

Fungsi pengenalan, tujuan dari promosi yaitu agar produk yang hendak dijual bisa diketahui oleh masyarakat. Biasanya produk dipromosikan hanya berisi informasi-informasi dasar. Contohnya adalah informasi merek, harga produk, keunggulan produk yang dipromosikan dibanding dengan produk lain.

2. Fungsi Penawaran

Seorang konsumen bukan hanya diajak untuk mengetahui informasi dari produk atau jasa yang ditawarkan, tetapi juga menawarkan pada konsumen supaya mengambil suatu keputusan untuk tergerak membeli. Misalnya untuk pembeli 100 pertama akan memperoleh potongan harga atau diskon sebesar $25 \%$ dan gratis souvenir dompet atau aksesoris.

3. Fungsi Penjagaan Konsumen Pada fungsi ini lebih menekankan pada 
kuantitas transaksi dan bukan kuantitas jumlah konsumen. Yang lebih penting dilakukan yaitu menyediakan pelayanan agar konsumen tetap setiap pada produk. Misalnya yaitu promosi hanya member (member only) di bisnis-bisnis tertentu seperti MLM dan lain sebagainya.

4. Fungsi Perbaikan

Di fungsi perbaikan promosi yaitu untuk melakukan perbaikan kesalahan yang pernah dilakukan baik oleh pemilik produk atau tim di perusahaan. Bisa disebut juga dengan sebagai permintaan maaf dari produsen terhadap konsumen. Misalnya adalah ketika ada yang menjual buku "Cara Budidaya Jamur Tiram" yang dilengkapi dengan $\mathrm{CD}$ tutorialnya, tetapi pada kenyataanya penulis tersebut lupa untuk memasukkan CD didalam buku, sebagai permintaan maaf, maka penulis akan memberikan $\mathrm{CD}$ tutorial tersebut ditambah dengan souvenir terhadap pembeli.

\section{Pengaruh produk dan Promosi terhadap Keputusan Pembelian Smartphone VIVO di Kota Lubuklinggau}

Berdasarkan hasil perhitungan, maka diperoleh nilai $\mathrm{b} 1=0,605, \quad \mathrm{~b} 2=0,355$ dan nilai $\mathrm{a}=11.052$, kemudian nilai $\mathrm{a}$ dan $\mathrm{b}$ disusun ke dalam persamaan regresi linear berganda $\mathrm{Y}=\mathrm{a}+\mathrm{b} 1 \mathrm{X} 1+$ b2X2, maka persamaan regresinya adalah $\mathrm{Y}$ $=11 \cdot 052+0,605 \mathrm{X} 1+0,355 \mathrm{X} 2$. Arti persaman tersebut adalah bahwa nilai konstanta sebesar $a=11.052$ ini berarti bahwa apabila tidak ada produk dan variabel promosi maka keputusan pembelian sebesar 11.052, sedangkan nilai koefisien regresi sebesar b1 $=0,605$ ini berarti setiap terjadi perbaikan satu satuan variabel produk akan mempengaruhi variabel keputusan pembelian sebesar 0,605 satuan. Kemudian nilai koefisien regresi sebesar b2 $=0,355$ ini berarti setiap terjadi peningkatan satu satuan variabel promosi akan mempengaruhi keputusan pembelian sebesar 0,355 satuan.

Dari hasil perhitungan diperoleh besarnya nilai koefisien determinasi $\left(\mathrm{R}^{2}\right)$ sebesar 0,754 yang berarti bahwa $75,4 \%$ baiknya produk dan promosi dapat dijelaskan oleh indikator- indikator yang ada di dalam produk dan promosi, sedangkan sisanya sebesar $(100 \%-75,4 \%=24,6 \%)$ dijelaskan oleh sebab-sebab yang lain seperti distirbusi, harga dan lain-lain.

Hasil perhitungan uji $\mathrm{F}$ diperoleh nilai fhitung sebesar $=56.853$ lebih besar dari nilai ftabel $=3,25$ dan probabilitas (sig. $0.000)$ lebih kecil atau kurang dari 0.05 , maka $\mathrm{Ha}$ : Di terima dan H0 : Ditolak. Yang berarti ada pengaruh yang signifikan produk dan promosi secara bersama-sama terhadap keputusan pembelian Smartphone Merek VIVO di Kota Lubuklinggau.

Sesuai dengan Indikator keputusan pembelian, Kemantapan pada sebuah produk. Kebiasaan dalam membeli produk. Memberikan rekomendasi kepada orang lain. Melakukan pembelian ulang. Kotler (2016:325). Dari hasil perhitungan pengolahan data kuesioner, bahwa responden setuju Produk yang kualitas baik akan banyak diminati masyarakat. Brand Smartphone VIVO menjadi alasan masyarakat untuk membeli. Tipe produk menjadi faktor utama keputusan pembelian masyarakat. Kebiasaan masyarakat membeli produk dengan harga yang murah dan dapat dijangkau memberikan keuntungan tersendiri bagi perusahaan. Masyarakat yang sudah mengetahui kualitas produk akan melakukan pembelian ulang. Keputusan pembelian ulang biasanya akan disertai dengan ajakan untuk yang lain agar ikut membeli produktersebut.

Hasil Penelitian ini dapat dikaitkan dengan hasil penelitian- penelitian terdahulu yang dilakukan Ipa Audia. 2017. Pengaruh Kualitas Produk dan Harga terhadap Keputusan Pembelian Masker Wajah Mustika Ratu (Studi kasus pada Konsumen Kec. Tembalang Kota Semarang). Penelitian 
ini memfokuskan pada pengaruh kualitas produk dan harga terhadap keputusan pembelian konsumen di Kec. Tembalang Kota Semarang. Hasil penelitian menunjukan kualitas produk berpengaruh terhadap keputusan pembelian sebesar 21,5\%. Harga berpengaruh terhadap keputusan pembelian sebesar $29,7 \%$. Secara simultan kualitas produk dan harga berpengaruh terhadap keputusan pembelian sebesar $35,6 \%$.

Demikian juga penelitian yang dilakukan oleh Heni. 2017. "Pengaruh Bauran Pemasaran Terhadap Keputusan Pembelian Smartphone Merek Samsung Pada Mahasiswa Universitas Alkhairaat Palu". Tujuan penelitian ini untuk mengetahui dan menganalisis pengaruh bauran pemasaran terhadap keputusan pembelian smartphone merek Samsung pada mahasiswa Universitas Alkhairaat Palu. Hasil penelitian ini menunjukkan bahwa secara simultan bauran pemasaran berpengaruh signifikan terhadap keputusan pembelian, dengan nilai sig 0,000 . Secara parsial dengan standar $\alpha=$ 0,05 diperoleh hasil penelitian Produk (X1), Harga (X2), Tempat (X3), dan Promosi (X4) berpengaruh signifikan terhadap keputusan pembelian dengan nilai sig masing-masing sebesar 0,007, 0,000. 0,012 , dan 0,000 . Keempat variabel. ini berpengaruh sebesar 0,876 atau $87,6 \%$ terhadap keputusan pembelian sedangkan sisanya sebesar $12,4 \%$ dipengaruhi oleh variabel lain.

Dari penelitian relevan di atas menjadi acuan peneliti untuk meneliti masalah yang sama yaitu tentang produk, promosi dan keputusan pembelian. Hasil penelitian yang peneliti lakukan menunjukkan produk dan promosi berpengaruh secara bersama-sama terhadap keputusan pembelian Smartphone Merek VIVO di Kota Lubuklinggau.

\section{KESIMPULAN}

Berdasarkan hasil penelitian dan pembahasan yang peneliti lakukan maka dapat disimpulkan bahwa;

1. Produk berpengaruh secara parsial terhadap Keputusan Pembelian Smartphone Merek VIVO di Kota Lubuklinggau, hal tersebut dibuktikan dari nilai thitung lebih besar dari ttabel, yaitu 5.871> 2,021 dan tingkat signifikan sig $=0,10$,

2. Promosi berpengaruh secara parsial terhadap Keputusan Pembelian Smartphone Merek VIVO di Kota Lubuklinggau, hal tersebut dibuktikan dari nilai thitung lebih besar dari ttabel, yaitu $3.441>2,021$ dan tingkat signifikan sig $=0,10$.

3. Produk dan Promosi berpengaruh secara simultan terhadap Keputusan Pembelian Smartphone Merek VIVO di Kota Lubuklinggau, hal tersebut dibuktika dari nilai fhitung sebesar $=$ 56.853 lebih besar dari nilai ftabel $=$ 3,25 dan probabilitas (sig. 0.000) lebih kecil atau kurang dari 0.05 .

\section{SARAN}

Peneliti memberikan saran yang nantinya diharapkan memberikan manfaat bagi Ratu 3G Cell lubuklinggau, sebagai berikut :

1. Ratu 3G Cell Lubuklinggau diharapkan dapat memberikan potongan harga untuk Smartphone Merek VIVO, agar penjualan dapat meningkat dan dapat bersaing dengan brand dan merek lain.

2. Ratu 3G Cell Lubuklinggau diharapkan dapat meningkatkan promosi, yang terdiri dari periklanan, sales promosi, penjualan langsung, agar masyarakat tertarik untuk melakukan pembelian Smartphone Merek VIVO.

\section{DAFTAR PUSTAKA}

[1] Abdurrahman, Nana Herdiana. 2015. Manajemen Strategi Pemasaran. Cetakan Ke-1. 
Bandung: CV Pustaka Setia.

[2] Azanul,

Atiya. 2016.

Langkah-langkah

PenetapanHarga.(Htpss//Aretikel//a

zanulayah.blogspot.co.id. diakses

20 Maret 2019).

[3] Binsar. 2016. Pengaruh Citra Merek dan Daya Tarik Iklan Terhadap Keputusan Pembelian Produk Smarthpone VIVO Pada Mahasiswa STIE ITMI. Jurnal ilmiah "INTEGRITAS" Vol.2 No. 1 Maret 2016.

[4] Ferry, Rinaldi. 2015. Konsep Strategi Pemasaran dan Bauran Pemasaran 4P (Marketing Mix). Artikel:

(https://www.kembar.pro. diakses 18 Maret 2019).

[5] Gita .2014. Analisis Bauran Pemasaran Pada Pembelian Sepeda Motor Honda. Jurnal Ilmiah Untag Semarang. Vol 5. No 3. Hal 24.

[6] Heni. 2017. Pengaruh Bauran Pemsaran terhadap Pembelian Smarthpone Samsung Pada Mahasiswa Universitas Alkhairat Palu. Jurnal Ilmu Manajemen Universitas Tadulako Vol. 3, No. 3, September 2017, 279-288 ISSNONLINE 2443-3578/ISSN PRINTED 2443-1850.

[7] Ipa Audina. 2017. Pengaruh Kualitas Produk dan Harga terhadap Keputusan Pembelian Masker Wajah Mustika Ratu (Studi Kasus pada Konsumen Kec.Tembalang Kota Semarang). Jurnal.

[8] Kotler, Philip., dan Gary Armstrong. 2018. Prinsip-prinsip
Pemasaran. Edisi 1, Jakarta: Erlangga.

[9] Malau, Harman. 2017. Manajemen Pemasaran. Cetakan kesatu. Bandung: Alfabeta.

[10] Margaretha. 2016.MARKETING MIX THEORETICAL ASPECTS. Journal Vol.4. No 3. Hal 32.

[11] Nami. 2013. Strategi bauran pemasaran Di Agrowisata Buana Ametha Sari. Jurnal Vol 4 No 2. Hal.45.

[12] Riefirmansyah. 2016. Pengertian bauran Pemasaran Marketing Mix. Artikel:

(Blogspot.co.id/2016/03.html diakses 17 Maret2019)

[13] Sugiyono. 2015. Metode Penelitian Manajemen. Cetakan ke-4. Bandung: Alfabeta.

[14] Sunyoto, Danang. 2016. Dasar-dasar Manajemen Pemasaran. Cetakan Ke-4. Yogyakarta:CAPS.

[15] Syofian, Siregar. 2014. Statistik Parametrik untuk Penelitian Kuantitatif. Jakarta: PT. Bumi Aksara.

[16] Zen Zen Guisi. 2018.The Effect Of Marketing Mixed Strategy on Marketing Performance and Competitive Excellence In Shopping Mall In Bandung and Denpasar Regency. Jurnal Ekonomi dan Bisnis, Vol.5 No.1. 